\title{
PROFILE OF A DAOYIN TRADITION: THE 'FIVE ANIMAL MIMES'
}

\author{
Wang Shumin 王淑民 ANd Penelope BarretT
}

\begin{abstract}
According to the Lingshu 㧼樞 (Numinous Pivot) section of Huangdi neijing 黃帝內經 (The Inner Canon [of Medicine] of the Yellow Emperor), the Yellow Emperor (said by legend to have reigned c. 2698-2599 BCE) read all the remedy literature, and distilled from it five methods of treating illness. The first of these was Daoyin xingqi 導引行氣 (Guiding and stretching and moving qi). This article traces the history of the daoyin exercise traditions involving animal impersonation from pre-Qin China to the present day. It uncovers a tale of transformation, on the one hand indicative of the therapeutic power invested in animals in early Chinese culture, and on the other of a practice sufficiently plastic to lend itself to unarmed combat and community sports - an emblem at once of self-determination and conformity.
\end{abstract}

This article profiles a specific tradition of daoyin (Chinese therapeutic gymnastics) involving animal mimesis, through religious and medical literature, and describes its survival in modern Chinese practice. Lü Shi chunqiu 呂氏春秋 (Mr Lü's Spring and Autumn Annals) (c. 239 BCE), 'Gu yue pian' 古樂篇 (Volume on Ancient Music) relates:

At the beginning of the reign of Tao Tang Shi 陶唐氏 [another name for the semi-legendary sage-king Yao 堯, supposed to have reigned in the third millennium BCE], there was an excess of Yin which accumulated and stagnated. The water courses were blocked, so that the water could not return to its origin; and the qi of the people was dammed up and stagnant, and their bones and sinews were contracted as with cold so that they could not be straightened. Therefore dances were performed to conjure this away.'

These dances, performed to bring health and harmony to the country and to the bodies of the dancers, were an early precursor of daoyin.

' Lü Shi chunqiu, juan 5 'Gu yue pian' 古樂篇, p. 3.

(C) Brill, Leiden, 2006

ASME 2,2 
The term daoyin itself is first recorded in the often-quoted locus classicus in the Keyi 刻意 (Single-mindedness) chapter of the Zhuangzi 莊子 (written down in the fourth-second century BCE)-actually a disparaging reference to the pursuit of physical wellbeing and longevity as an end in itself:

To huff and to puff, exhale and inhale, blow out the old and draw in the new, do the 'bear-hang' and the 'bird-stretch', interested only in long life - such are the tastes of the practitioners of 'guide-and-pull' exercises, the nurturers of the body, Grandfather P'eng's ripe-old-agers. ${ }^{2}$

The term daoyin is made up of two semantic elements: 導 'dao' [lead, conduct], and 'yin' 引 [pull, stretch]. English renditions range from the literal ('guiding and pulling') to the descriptive (therapeutic movement). It is glossed by the Jin 晉 (256-420) commentator Li Yi as 'dao qi ling he, yin ti ling rou' 導 氣令和, 引體令柔 (conducting $q i /$ breath and bringing harmony; stretching the body and bringing suppleness). ${ }^{3}$ In other words, by regulating the respiration, daoyin can achieve a smooth harmonious flow of $q i$ and by exercising the limbs it can increase agility, suppleness and grace.

The extract from Keyi shows that by the Warring States period (475-221 BCE), when Zhuangzi was written down, daoyin had become established as a physical cultivation technique in the quest for longevity, even if it fell somewhat short in the range of transcendental techniques aiming at immortality. The 'bear-hang' and the 'bird-stretch' are used to refer by synecdoche to the gymnastic component of daoyin, illustrating the centrality of animal impersonation in this context.

The roots of animal daoyin exercises have been traced to the exorcistic rites and shamanic dances recorded in the Warring States and early imperial period. ${ }^{4}$ They are a personal and secular cognate of collective rituals like the annual nuo 儺 festival, or Great Exorcism, in which the principal celebrant, a demon impersonator known as the Fangxiangshi 方相氏, wore an animal mask and a bearskin, and was assisted by twelve dancing officials dressed as animals. ${ }^{5}$ Just as the dances of the nuo festival served to expel pestilence and noxious

\footnotetext{
2 See Guo Qingfan 1961, p. 535. Tr. quoted from Graham 1981, p. 265. Graham renders the title of this chapter as 'Finicky Notions'; Victor Mair as 'Ingrained Opinions', Mair 1994, p. 144.

${ }^{3}$ See Guo Qingfan 1961, loc cit.

${ }^{4}$ Sterckx 2002, p. 186 et seq; Despeux 1989 pp. 237-40.

${ }^{5}$ Ibid. For a description of the nuo festival, see Bodde 1975, p. 75 et seq.
} 
influences from the land and body politic, so too animal daoyin could remove illness and its causes from the body of the practitioner and restore order there. The theme of animals travelling, which runs through all the animal mimes examined here, has obvious resonances with shamanic travel.

Recent scholarship has placed animal impersonation within larger paradigms of change and transformation that shape Chinese views of the cosmos. The essential text in this regard is Roel Sterckx' The Animal and the Daemon in Early China.

If western cosmologies have tended to present contingent physical phenomena as a mere (partial or distorted) reflection of a transcendent or ideal reality, in Chinese models of the world, all things partook of the same reality, 'through a system of correspondence which meshed the manifold phenomena of the world into a single fabric'. ${ }^{6}$ The boundaries between animals and human beings were at once less perilous and more permeable.

Within the animal kingdom, transformation was not limited by boundaries of form or species; at regular times, mice turned into quails, and hawks to pigeons. The shedding of form was not unique to observably metamorphosing animals, such as the reptiles, but common to many different beasts, some capable of spirit-like transfiguration. In the next quotation from Lü Shi chunqiu, we can see how, in ritual theory, the phases of the year are, in part, determined by the metamorphoses of species. ${ }^{7}$

During the third month of Spring, the sun is in Stomach. ${ }^{8}$ At dusk the constellations Seven Stars culminates and at dawn the constellation Herdboy culminates.

The correlates of this month are the days jia and $y i$, the Sovereign Taihao, his assisting spirit Goumang, creatures that are scaly, the musical note jue, the pitch-standard named Maid Purity, the number eight, tastes that are sour, smells that are rank, and the offering at the door. At sacrifice, the spleen is given the pre-eminent position.

The Paulownia trees begin to bloom, the mole is transformed into a quail, ${ }^{9}$ rainbows begin to appear and the duckweed starts to grow... ${ }^{10}$

${ }^{6}$ Harper 1985, p. 467.

7 Lü Shi chunqiu juaoshi 13, p. 677; Huainanzi 11.18a. See also Lloyd and Sivin 1992, pp. 32-3; Needham 1956, pp. 261-5; Loewe 2004, pp. 466-8.

8 A star listed in the constellations of Shi Shi 石氏.

${ }^{9}$ Our italics.

${ }^{10}$ Lü Shi chunqiu, 14.2, trans. adapted from Knoblock and Riegel 2000, p. 95. 
Human beings could literally metamorphose into animals and even inanimate objects. ${ }^{11}$

These ideas were powerful and very enduring. For the sixteenthcentury naturalist Li Shizhen 李時珍 (eulogised as the father of China's scientific research tradition) the intertransformability of beings and objects was fundamental to his vision of a coherent, intelligible universe. Here is the concluding passage of his encyclopedia of materia medica, Bencao gangmu 本 草綱目, which rounds off a discussion of transformation at the end of the section on 'Humans' (ren 人), and may act as an envoi for the entire work:

That is to say, these changes are all due to the oneness of $q i$. Those who study these things superficially, and view them partially may find them fantastic, but in the context of the infinite changes of time and the cosmos, why should anyone think them so? ${ }^{12}$

By assimilating themselves to animals, human beings could connect themselves with the creative and transformative forces of nature and the typologies of change that structured the universe. But animals were not only an aspect of the natural macrocosm; they were also immanent within the microcosm of the body. Animal spirits dwelt in the organs:

The concept of spirits resident in the organs exists in Taiping jing 太平經 (Canon of heavenly peace), which may be datable in part to the later Han Dynasty. A similar idea seems to develop independently in the Daoist meditation traditions at least from the fifth century CE if not much earlier. ${ }^{13}$

And animal imagery was central to the language of disease and therapy:

Animals [lent] their sounds, shapes and textures to convey knowledge about the body... [These were] not just transcendental transformations but also pathological transformations. ${ }^{14}$

Animals were also identified with social and moral categories. Actual and symbolic animals were involved in the construction of social identities and hierarchies. ${ }^{15}$ In the earliest known visual representa-

1 See Sterckx 2002, especially ch. 6 'Changing animals' for numerous examples.

12 Bencao Gangmu, vol. 2, p. 1944.

${ }^{13}$ Lo 2006, citing Taipingïng hejiao, pp. 14, 22, and 27.

14 Ibid.

15 See Sterckx' detailed discussion in Sterckx 2002, esp. ch. 2 'Animals and Officers'. 


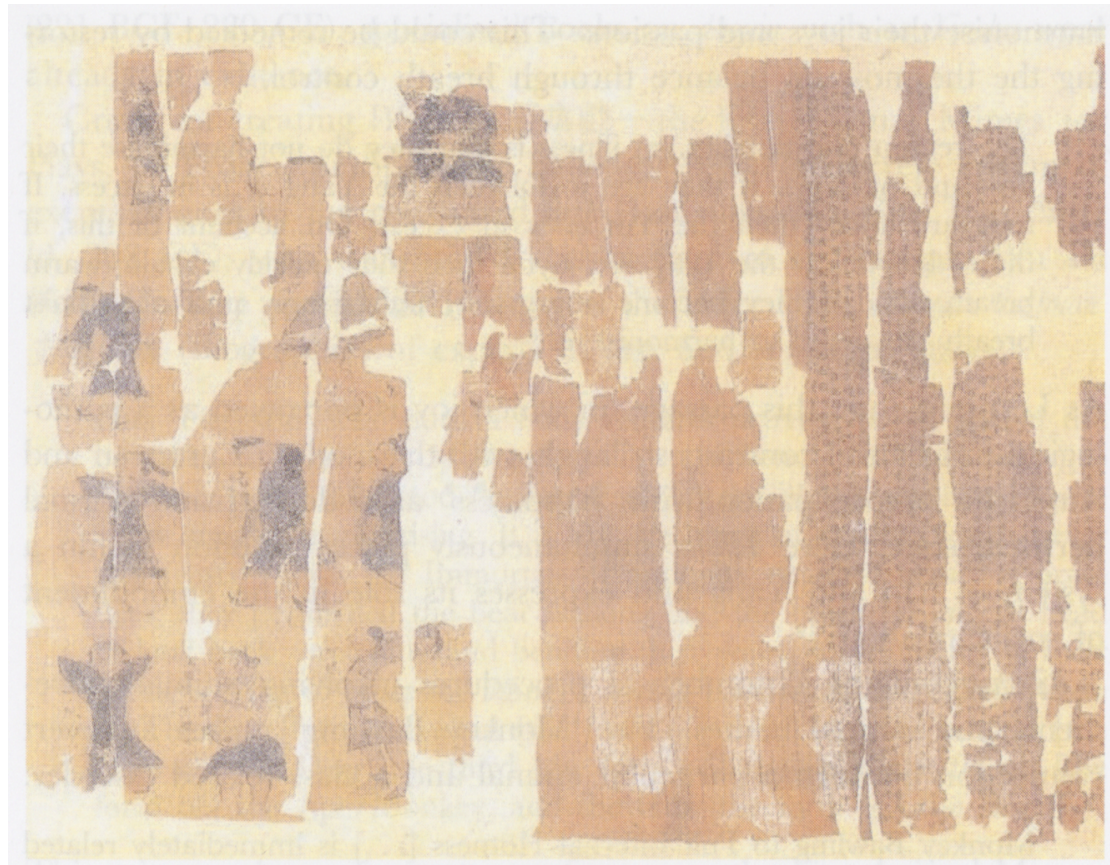

Fig 1. Section of the Mawangdui Daoyin tu 'guiding and pulling chart' 導引圖

[Source: Wellcome Library, Medical Photographic Library, Image no. L0040263]

tions of daoyin, the gendered and socially nuanced images of the Daoyin Chart from Mawangdui, social categories visibly coincide with animal types as well as constructions of disease [see fig. 1]. ${ }^{16}$ The Daoyin Chart is a splendid set of paintings on silk, found in the tomb of Li Cang 利蒼, Marquis of Changsha (closed 168 BCE) at Mawangdui 馬王堆, Changsha 長沙.

Yinshu 引書 (Pulling Book or Stretching Book), a bamboo-strip text recovered archaeologically from Tomb 247 at the Zhangiiashan 張家山 burial site at Jiangling, Hubei province (closed 186 BCE), explains very specifically how ways of becoming ill and curing oneself correlate with social class. Whereas common people suffered from the vicissitudes of their environment, the nobility (guiren 貴人) fell ill when their own Yin or Yang qi grew to excess, due to failure to

${ }^{16}$ Lo forthcoming 2007. 
harmonise their joys and passions. This could be remedied by restoring the thermostatic balance through breath control: ${ }^{17}$

The reason that nobility get illness is that they do not harmonise their joys and passions. If they are joyful then the Yang $q i$ is in excess. If they are angry then the Yin $q i$ is in excess. On account of this, if those that follow the Way are joyful then they quickly exhale (warm breath), and if they become angry they increasingly puff out (moist breath), in order to harmonise it. ${ }^{18}$

As Lo points out, this passage (in which joy is portrayed as a pathological imbalance) contrasts strikingly with the modern European and American preoccupation with 'happiness' as a desired and normal personal state. Here Yinshu simultaneously places emotion within a system of Yin and Yang and expresses its role in the embodiment of social relations. ${ }^{19}$

Yinshu contains a number of procedures involving animal movements and animal names. The 'Monkey Bawling' makes an overt connection between a particular animal and a class-related disorder:

Monkey Bawling to Pull Internal Hotness [...] is immediately related to a physical disorder - the disorder in question being the plight of the noble who, we have seen, by virtue of his class, is committed to remedying unresolved emotional and thermostatic excess. ${ }^{20}$

As a social practice, animal mimes embody a tension between individualism and conformity that runs through self-cultivation culture in general. By taking control of one's $q i$ and channelling animal power, one could become master of one's body and one's own destiny, instead of remaining at the mercy of one's environment. And yet in order to do so, one had to submit oneself to an external discipline and allow oneself to be subsumed into a cosmic hierarchy where, ultimately, it was the emperor's body and its rituals that determined peace in the kingdom and collective survival. ${ }^{21}$

By the late Warring States period, daoyin had become codified as a scheme of therapeutic practices. The Daoyin Chart from Mawangdui, discussed in greater detail below, shows people of both sexes and various ages performing daoyin exercises. By the Qin-Han period

\footnotetext{
17 See discussion in Lo 2006.

18 Yinshu, Slips 108-9. Trans. quoted from Lo 1998, p. 354.

19 Lo forthcoming 2007.

${ }^{20}$ Ibid.

${ }^{21}$ Lo 2006.
} 
(221 BCE-220 CE), specialised books on daoyin such as Yinshu were already in existence.

Credit for creating Wuqin xi 五禽戲一the Five Animal Mimes (or Plays, or Frolics, or Sport, or Ballet... $)^{22}$ as a discrete system of exercises goes to the celebrated late-Han physician Hua Tuo 華佗 (d. $203 \mathrm{CE}$ ), who transmitted this method to his disciple $\mathrm{Wu} \mathrm{Pu}$ 吳普. Hou Han shu 後漢書 (History of the Later Han), Fangshu liezhuan 方術列傳 (Biographies of experts in arts and remedies) states:

Hua Tuo said: The human body requires activity, but it should not be taken to extremes. Movement allows $q i$ from solid food (grain) to disperse, keeps the blood flowing freely in the blood vessels, and prevents diseases from arising. It is like the hinge of a door, which never rots [rusts]. Thus the Immortals of antiquity engaged in daoyin practices; they performed the bear walking and the hawk turning its head to look back, stretching and bending their waists and moving all their joints, seeking to postpone aging. I myself have a method called Wuqin $x i$. The first [form] is called [the form of] the Tiger, the second [the form of] the Deer, the third [the form of] the Bear, the fourth [the form of] the Ape/Monkey, and the fifth [the form of] the Bird. ${ }^{23}$

This passage, the earliest extant reference to the Five Animal Mimes, makes a strikingly explicit connection between 'immortal sages' and the animal kingdom. In the words of Sterckx:

If numinous power among animals was identified with the ability to metamorphose, transcend one's habitat, and respond to changing circumstances, these were precisely the features associated with the human sage. ${ }^{24}$

The Five Animal Mimes then, is an ancient Chinese type of therapeutic gymnastic exercise, or daoyin, based on animal mimesis. The 'Immortals of antiquity' (gu zhi xian zhi 古之仙者) whose authority Hua Tuo invokes were the adherents of pre-Han immortality cults, who had devised methods of physical culture involving the imitation of animal movements. Early on, various versions of mimetic daoyin co-existed; and animal mimes featuring various numbers of creatures are attested, but in the course of transmission, the Five Animal Mimes gradually asserted itself as the dominant form. Together, the received

22 In early Chinese, 'qin' 莗 designated birds and beasts in general, and ' $x i$ ' 戯 could mean 'play', 'sport' or 'game'.

${ }^{23}$ Hou Hanshu, 82 juan xia 'Fangshu liezhuan', 72 xia, pp. 2739-40.

${ }^{24}$ Sterckx 2002, p. 185. 
literature and archaeological evidence afford tantalising glimpses of this process.

\section{Gymnastic exercises including numerous animal forms in the Mawangdui Daoyin Chart}

The Daoyin Chart was discovered in 1973 in Tomb 3 of the Han (206 BCE-220 CE) burial site at Mawangdui 馬王堆, Changsha 長沙, present-day Henan province, among the funerary objects of the son of Li Cang 利蒼, Marquis of Changsha (interred 168 BCE, 12th year of the first reign period of the Han emperor Wendi 文帝). It is painted on a silk scroll that also contains a text called 'Quegu shi qi pian' 卻穀食氣篇 (On Abstaining from Grain and Feeding on Qi) - a practice later adopted as Daoist technique - as well as a version of one of the channel (vessel/meridian) texts, which suggests an association between the development of daoyin and the channel therapies on which later acu-moxa treatments were based. ${ }^{25}$

Given that the date of internment is little more than half a century after the end of the Warring States period (221 BC), the scroll presumably formed part of a now-lost Qin or even pre-Qin book. Probably nine of the 44 images represent forms imitating the movement of animals or insects: the mantis, the crane, the dragon, the goshawk, the bird, the monkey or ape, the bear, the tortoise/turtle, and the zhan 鸇 hawk. ${ }^{26}$

The images in the Daoyin Chart display obvious parallels in form and nomenclature with the therapeutic exercises recorded in Yinshu, ${ }^{27}$ as also with sexual cultivation practices. ${ }^{28}$

\section{Mime of the Mantis (Image 8)}

The mantis has long, powerful front legs, which it keeps raised, ready to clutch at its prey. In this form, the practitioner imitates the mantis by raising his/her arms and brandishing them to left and right.

\footnotetext{
${ }^{25} \mathrm{He}$ and Lo 1996, pp. 112-16.

${ }^{26}$ Ma Jixing 1992, pp. 847-66. See reproductions in Daoyintu.

${ }^{27}$ For a discussion of the parallels between the Mawangdui Daoyin Chart and Yinshu, and a summary of relevant scholarship, see Harper 1998, pp. 310-16.

${ }^{28}$ Cf. Umekawa 2005, pp. 264-6 and passim.
} 


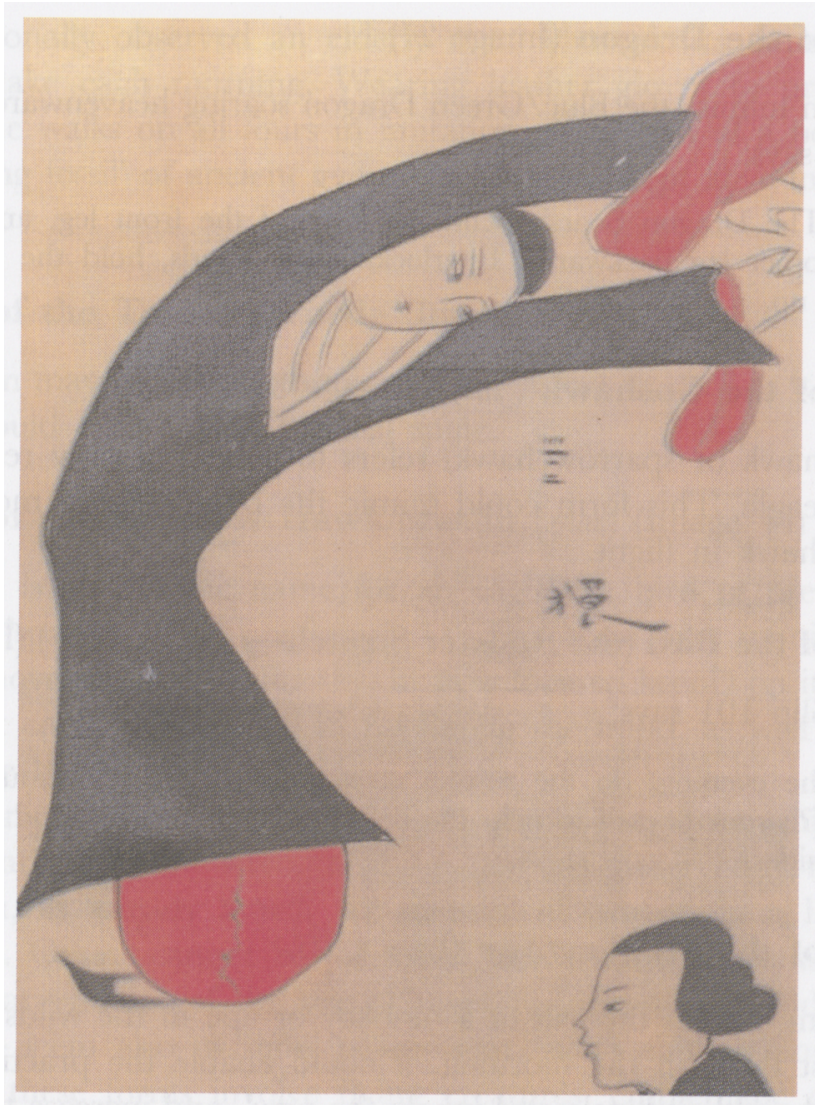

Fig 2. Praying Mantis from a reconstruction of the Daoyin tu [Source: Wellcome Library, Medical Photographic Library, Image no. L0036007]

This exercise may be beneficial for the muscles of the mid section and arm mobility. According to Kinshu, the Praying Mantis is good for heng mai 恒脈 (the 'constant channel') [see fig. 2]. ${ }^{29}$

\section{Mime of the Crane (Image 25)}

This form imitates the movement of the crane taking off and flying, and also involves vocal mimicry of the call of the crane. It may be performed as an exercise for the arms and for improving lung capacity.

${ }^{29}$ Yinshu, trans. in Lo 1998, p. 353. Heng mai may refer to one of the more obvious sites of the beating of the pulse, e.g. over the carotid artery. 
Mime of the Dragon (Image 27)

This form mimics the Blue/Green Dragon soaring heavenward. Minshu, Slip 17, says:

In 'The Dragon Soars', bend the knee of the front leg, and extend the other leg backwards. Interlocking the hands, hold the knee and look up.

Mime of the Goshawk (yao $)^{30}$ (Image 31)

Yao (goshawk or sparrow hawk) refers to a bird of prey resembling a small eagle. This form could mimic the bold, darting movements of a goshawk in flight.

Mime of the Bird (the Rooster Stretch-ji shen 雞伸) (Image 32) Yinshu, Slip 101 says:

In the evening, do the rooster stretch to benefit the shoulders and hips(?); rock oneself to help the belly and heart; spin round to benefit the sides.

\section{Mime of the Monkey/Ape (Image 40)}

This form mimics the call of a monkey or ape in the wilds. If practised first thing in the morning, it could enable the practitioner to 'exhale the old and stale and inhale the new', and increase the intake of fresh air.

Yinshu refers to a 'Gibbon [or Ape] Walk', which is supposed to be good for pain in the shoulder (Slip 79), and possibly also a Gibbon [or Ape] Hold (Slip 22). ${ }^{31}$

\section{Mime of the Bear (Image 41)}

This form exercises the limbs and trunk through the imitation of the gait of the bear. Yinshu says that the 'Bear Warp' is good for the muscles of the back (Slip 100), and cures backache (Slip 50). ${ }^{32}$ In Taoranting 陶然亭 [Joyous Pavilion] Park in Beijing, the author [Wang]

30 The identification of this form is open to discussion, as the graph ' $y a 0^{\prime}$ lacks the bird radical. See Harper 1998, p. 314, n. 3.

${ }_{31}$ Yinshu, trans. in Lo 1998, p. 351 and p. 345.

${ }^{32}$ Yinshu, trans. in Lo 1998, p. 353 and p. 348. 
has personally observed an elderly man who mimics animal walks by the lake each morning. Wearing leather gloves to protect his hands, he walks on all fours in imitation of the gait of a bear. This is a 'living fossil' of ancient gymnastic practice, kept alive in popular tradition.

\section{Mime of the Tortoise/Turtle (Image 42) ${ }^{33}$}

This form may mimic the tortoise stretching out its neck as it breathes in. It would exercise the cervical spine.

\section{Mime of the Sparrow Hawk/Merlin (zhan) (Image 44)}

Zhan 鸇 is an archaic name for an eagle-like bird of prey, translated as 'sparrow hawk' or 'merlin'. ${ }^{34}$ This form may mimic a bird of prey hovering high in the sky, its eyes focused keenly on its quarry below. It could be of value in regulating the mind, as well as exercising the body.

The animal mime forms described above are those which have been identified on the strength of the captions preserved in the scroll (although, as already noted, the identity of two of them has been disputed). Others cannot be identified with certainty because of the fragmentary nature of the text. However, Images 7, 9 and 11, for example, seem also to show postures imitating animal movements. Most of these forms involve flying creatures, emblematic of moral and spiritual transcendence and transition..$^{35}$

It should be observed that the titles and captions name the animals concerned, while information about the movements to be carried out is largely carried by the visual images: that is, a performative use of language runs parallel with the physical performance of animal actions. As Sterckx notes: 'Naming as a therapeutic act of controlling uncanny creatures figures prominently in the context of healing and demonic medicine in Warring States texts. ${ }^{36}$

Of the multiple animal forms that have been identified in the Mawangdui Daoyin Chart, three were carried over into the Five Animal Mimes, i.e. the mimes of the Bear, the Monkey or Ape, and the Bird. Because only the visual images and titles for these three forms

${ }^{33}$ Harper casts doubt on this identification. See Harper 1998, p. 316, n. 3.

${ }^{34}$ The identity of this bird is discussed in Harper 1998, p. 316, n. 4.

${ }^{35}$ Cf. Sterckx 2002, p. 185 and passim; Lo forthcoming 2007.

${ }^{36}$ Sterckx 2002, p. 220. 
survive in the Daoyin Chart, they can be interpreted only through comparison with the account of the Five Animal Mimes given in Yangxing yanming lu 養性延命錄 (Account of Cultivating Nature and Extending life), 'Daoyin anqiao' 導引按蹺 (Therapeutic gymnastics and massage), attributed to Tao Hongjing 陶弘景 (456-536 CE, Liang period 502-557). Tao Honging was a distinguished scholar and patriarch of the Shangqing School of Daoism, who was responsible for collecting and editing a large body of earlier Daoist literature. For example, the description of the Mime of the Bird in Yangxing yanming lu says:

In the Mime of the Bird, one places both hands on the ground and raises one foot. One stretches out the arms and flaps the shoulders [like wings]. This should be done energetically 27 times each side. One then adopts a sitting posture with legs outstretched, and grasps and pulls the toes with the hands. Both arms must be raised, bent and stretched seven times each. ${ }^{37}$

Three of the actions described-one 'places both hands on the ground', 'stretches out the arms', and 'flaps the shoulders [like wings]'-correspond to Image 32 in the Daoyin Chart, which depicts a man bending forward with his arms hanging down and his head raised, looking straight ahead. However, Yangxing yanming also includes a seated sequence. This is consistent with the proposition that the Five Animal Mimes in rangxing yanming lu developed out of multiple animal forms such as those shown in the Daoyin Chart, or in other words that Hua Tuo's Five Animal Mimes have as their ultimate source mimetic gymnastic techniques of the pre-Qin era.

\section{The Eight Animal Mimes (Baqin xi 八金戲)}

The Eight Animal Mimes is documented in Yi xia zhi yan 醫暇后言, by the Qing (1644-1911) author Cheng Lin 程林. This text chiefly consists of medical anecdotes and observations, but juan 1 contains the following passage:

There are the Five Animal Mimes of Hua Tuo, and in the Daoist classics we also find the so-called Eight Animal Mimes: The bird spread-

\footnotetext{
37 Tao Honging (attr.), Yangxing yanming lu, latter juan, pian 5 'Daoyin anqiao', no page numbering.
} 
ing its wings; the mallard bathing; the monkey leaping; the hawk gazing; the tiger looking round; the jiao [a kind of pheasant] breathing in; and the tortoise withdrawing into its shell. ${ }^{38}$

Unfortunately, there are no illustrations or further details. Judging from their titles, all of which have parallels in the Daoyin Chart, the Eight Animal Mimes are derived from pre-Qin multiple animal forms, and thus share a common origin with the Five Animal Mimes. The Mime of the Deer is the only one of the Five Animal Mimes that is missing from the Eight Animal Mimes.

\section{The Six Animal Mimes (Liuqin xi 六金戲)}

The Six Animal Mimes is documented in Huainanzi 淮南子 (Western Han period, 206 BCE-25 CE), attributed to Liu An 劉安 (c. 179-122 BCE), 'Jingshen xun' 精神訓 (Teachings on the Spirit), which states:

As to breathing exercises, breathing out the old and stale and breathing in the new; 'the bear walking', 'the bird spreading its wings', 'the mallard bathing', 'the monkey capering', 'the hawk gazing', and 'the tiger turning to look back', these are the practices of those who cultivate the physical body. ${ }^{39}$

Of the Six Animal Mimes, three - the forms of the Bear, the Bird and the Ape/Monkey - are found in the Daoyin Chart. The remaining three either have become obliterated, or were never represented there. Two of these are, however, described briefly in Yinshu (where 'the mallard bathing' ( $f u y u$ "浴) is denoted as 'the mallard washing' ( $f u$ wo r behind the back and shake the head.' (Slip15); 'To do the tiger pull/stretch, step forward with one foot, and bow forward with one arm raised in a bold, threatening gesture.' (Slip 24); 'To do "the tiger bowing", keeping the arms together, wave them over the shoulders to left and right.' (Slip 26). ${ }^{40}$ The imitation of the tiger bending backwards and forwards and the limb movements tally with the description of the Mime of the Tiger in Yangxing yanming l $u^{41}$

38 Ti xia zhi yan, former juan, p. 18.

${ }^{39}$ He Ning 1998, p. 527. There are no illustrations accompanying this passage.

40 Yinshu, cf. Lo 1998, pp. 287-9. The numbering of the slips in Lo's thesis is slightly different, as are some of the readings adopted.

${ }_{41}$ Tao Hongjing (attr.), Yangxing yanming lu, latter juan, pian 5 'Daoyin anqiao', no page numbering. 


\section{Five Animal Mimes}

The earliest extant record of the actual movements involved in the Five Animal Mimes is provided by Yangxing yanming $l u$ 養性延命錄 (Account of Cultivating Nature and Extending life), 'Daoyin anqiao' 導引按蹺 (Therapeutic gymnastics and massage):

In the Mime of the Tiger, one stands on all fours, takes three steps backwards, then three steps forwards, stretches at the waist, crosses the legs over, cranes the neck to look skywards, then steps backwards again, advancing and retreating seven times.

In the Mime of the Deer, one stands on all fours, and stretches the neck around to look behind one, three times to the left and twice to the right. One stretches out one's left and right leg, straightening and flexing in groups of three and two.

In the Mime of the Bear, one stands facing forwards, clasping the legs below the knee with both hands. Raising one's head, one stamps one's feet seven times on the left and seven times on the right. One squats down and paws the ground the ground with the left and right hand.

In the Mime of the Monkey/Ape, holding on to a fixed object as though climbing, one spins around, and extends and flexes the body, stretching upwards and downwards seventeen times. With the feet supported, one performs cartwheels, seven times to the left and right. One clasps the feet with the hands five times and pats the head seven times.

In the Mime of the Bird, one places both hands on the ground and raises one foot. One stretches out the arms and flaps the shoulders [like wings]. This should be done energetically 27 times each side. One then adopts a sitting posture with legs outstretched, and grasps and pulls the toes with the hands. Both arms must be raised, bent and stretched seven times each.

In the method of the Five Animal Mimes, the movements must be performed energetically, so as to work up a sweat. Once one is sweating, one rubs chalk into the body. This serves to eliminate the [impure] $q i$ of solid food (grain), increase strength, and expel numerous illnesses. If one can persist with this exercise, one will undoubtedly prolong one's life. ${ }^{42}$

Three centuries separate the lifetimes of Hua Tuo and Tao Hongjing, to whom Yangxing yanming $l u$ is traditionally attributed, but it is just plausible that these movement sequences approximate to Hua Tuo's

${ }^{42}$ Ibid. 
original Mimes. However, the forms as described are technically challenging, and as no illustrations exist, they are hard to translate into practice.

Though Hua Tuo's own account of the Five Animal Mimes has not survived, the Mimes were passed on in oral tradition, and are recorded in various written sources in diverse versions, some simple and some more elaborate, some 'softer' and some 'harder'. In the versions preserved within the Daoist canon especially, physical movements are combined with breathing exercises and contemplative and ideational techniques. Detailed instructions for practising the Five Animal Mimes, employing a mixture of graphics and textual description, are found in later manuals such as Zhou Lüjing's 周履靖 Yimen guangdu: Chi feng sui 夷門廣牘・赤鳳膸 (Marrow of the Crimson Phoenix) (Ming period, 1368-1644), Cao Wuji's 曹無極 Wanshou xianshu: Daoyin pian 萬壽仙書·導引篇 (The Immortals' Book of Longevity: Section on daoyin) and Xi Xifan's 席錫蕃 (Qing period) Wu qin wu gongfa tushuo 五离舞功 法圖說 (Illustrated Guide to the 'Dance [sic] of the Five Animals' gongfu technique) (Qing period). The practices recorded here differ considerably from the account in Yangxing yanming lu. Each of the Mimes constitutes a separate form, and the sequence of Mimes is codified as Tiger, Bear, Deer, Monkey/Ape, Bird. But the texts accompanying the pictures do not simply describe physical movements; they also include instructions on mental state and associated movements of $q i$ and blood. These documents provide vital evidence for modern researchers.

For example, here are the Five Animal Mimes as described by Zhou Lüjing's sixteenth-century Marrow of the Crimson Phoenix. ${ }^{43}$

\section{Xianmen's 羡門 ${ }^{44}$ Mime of the Tiger}

Hold the breath $(q i)$ and bow the head, clench the fists, adopt a stance like a tiger making a show of strength. As though you were holding something priceless in your hands, lift them gently and gradually, without releasing the breath, straighten up the body, gulp down air into the abdomen, allow the spiritual breath to rise and then descend again, be aware of it making a thunderous sound inside the abdomen. Do

${ }^{43}$ Cf Despeux 1988, pp. 102-11. The identification of the personages named in the titles of the Mimes follows Despeux' edition.

"4 Xianmen was an Immortal of antiquity, who underwent transformation through corpse-liberation. 


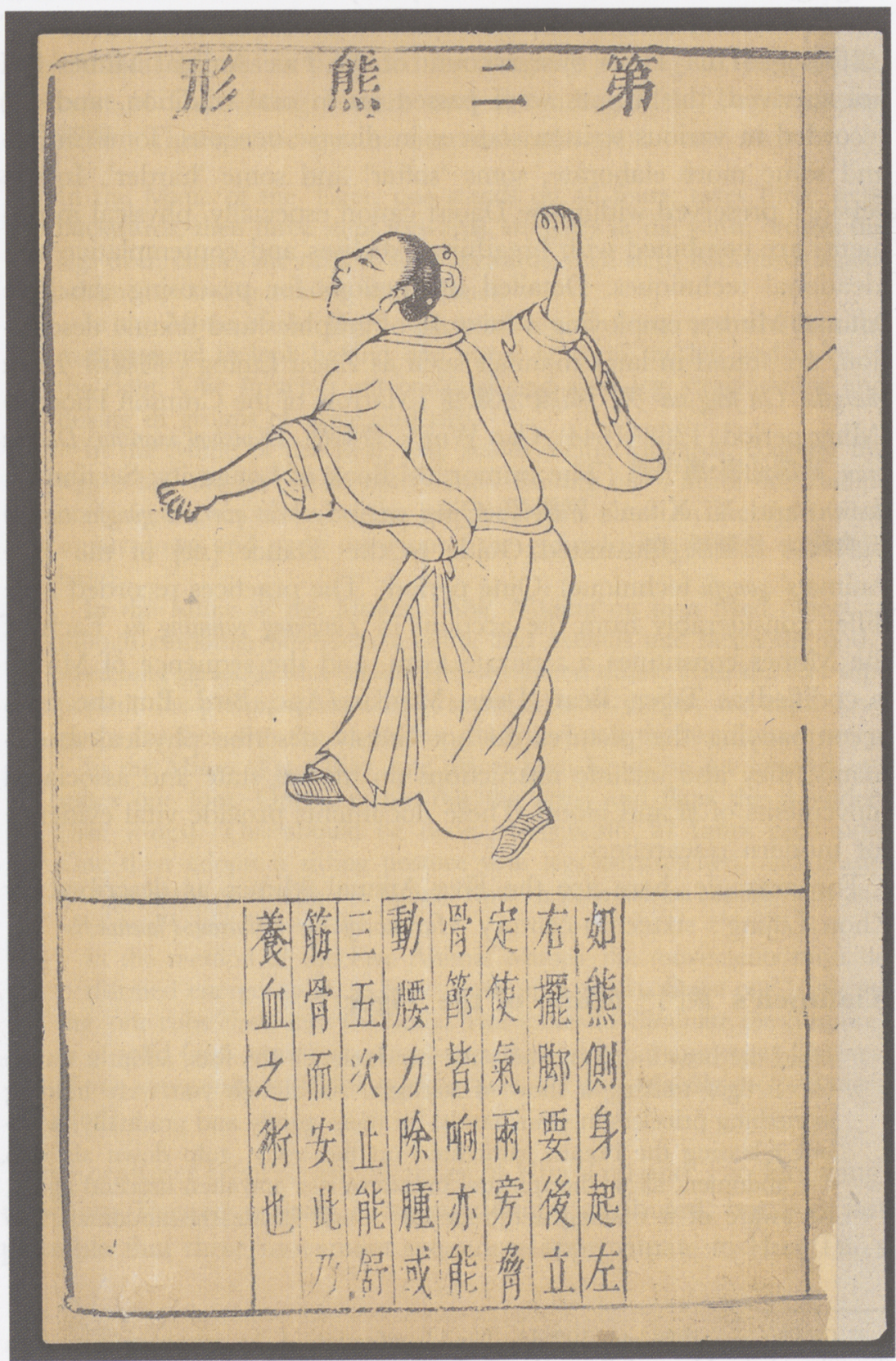




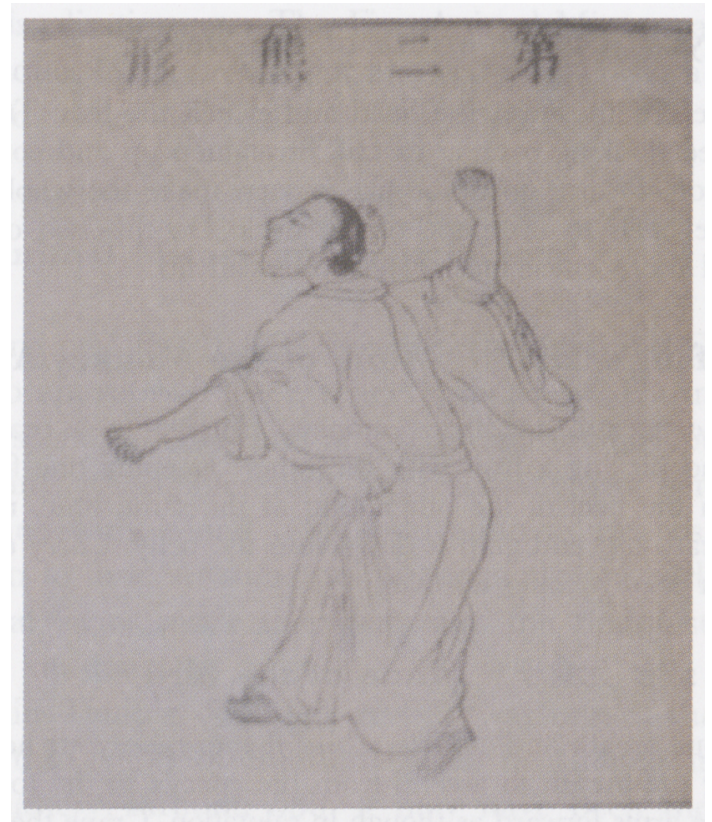

Fig. 3. 'Mime No. 2: The Bear' from the 'Five Animal Mimes' in Wanshou danshu 万寿丹书 (The Cinnabar Book of Longevity), Gong Juzhong 貲居中, 1631, held in the Library of Zhongguo zhongyi yanjiu yuan, Beijing.

Source: Wellcome Library, Medical Photographic Library, Image no. L0038958

this about five to seven times. Through this exercise, one can regulate and balance the $q i$ in the channels of the whole body, make the spirit bright and clear, and prevent the myriad diseases from arising.

\section{Gengsang's 庚慜 ${ }^{45}$ Mime of the Bear [See fig 3]}

Advance moving the body diagonally, like a bear, swinging yourself to left and right. Then stand still with one foot thrust forward. Make the breath resound against the ribs and joints on both sides. This can relieve tension in the lumbar region and get rid of abdominal bloating. Do this about 3-5 times, then stop. It can also loosen the muscles and joints, calm the mind and nourish the blood.

45 An Immortal of antiquity, and disciple of the legendary Laozi. 


\section{Shi Chengyi's 士成綺 ${ }^{46}$ Mime of the Deer}

Hold the breath, lower the head and clench the fists. Turn your head like a deer looking back at its tail. Straighten up and contract the kidney region. Prance on tiptoe like a deer, make the whole body quiver from the heels to the nape of the neck. Do this two or three times. It is still more efficacious if performed ad lib.

\section{Fei Zhangfang's 費長房 ${ }^{47}$ Mime of the Monkey/Ape}

Hold the breath, act like a monkey clinging to a branch with one hand and picking a fruit with the other. Keeping one foot in the air, pivot on the heel of the other foot; at the same time, move the spiritual breath $(q i)$ and gulp it down into the belly. Carry on till you feel that you are sweating all over.

\section{Yuancang zi's 元倉子 ${ }^{48}$ Mime of the Bird}

Hold your breath and act like a bird flying, raise your head and inhale allowing the breath to ascend from the coccyx to the top of the head. Bring the arms forward as though in salutation. Crane the head upwards and make the hands dance over the top of the head. ${ }^{49}$

Whereas Tao Hongjing's account of the Five Animal Mimes in Yangxing yanming $l u$ is largely confined to physical movements, and makes no mention of breathing, meditative techniques, etc., the descriptions in the Marrow of the Crimson Phoenix incorporate breathing methods as well as concepts such as cun si 存思 and yi shou 意守 (ways of focusing the mind in meditation) from the repertoire of Daoist yangsheng 養生 (nourishing life) practices.

As can readily be seen, animal mime practices underwent a process of simplification as regards the number of animal types, passing from the complex array of animal mimes in the Daoyin Chart through the Eight Animal and Six animal Mimes, to formalisation as the Five Animal Mimes. But within each Mime, a contrary process took place, from simplicity to complexity. By the Ming, simple physical exercises had developed into practices that involved gymnastics, techniques for

\footnotetext{
${ }^{46}$ A hermit of the Zhou period (c. eleventh century-256 BCE), who is supposed to have met the legendary Laozi.

47 An Immortal of the Han period (206 BCE-220 CE).

${ }^{48}$ Yuancang zi 元倉子 or Kangcang zi 尣倉子: another name for the Immortal Gengsang (see n. 43).

49 Zhou Lüjing, Chi feng sui, pp. 41-5.
} 
moving $q i$, visualisation, etc. The Five Animal Mimes came to unite daoyin, techniques for $q i$ movement and self-massage in a single gymnastic method.

\section{The Five Animal Mimes and martial arts}

From the Tang period (618-907) onward, Buddhist and Daoist adherents began to appropriate each others' practices..$^{50}$ During the Ming period, high social mobility and an expanding reading public helped fuel a boom in yangsheng literature. Representations of pervasive practices concerned with $q i$ and body cultivation as well as health and healing began to fuse. At some point - certainly not earlier than the Ming - animal forms made their way into the Buddhist domain of Shaolin 少林 martial arts.

The Shaolin Temple, founded in 495, was one of the early centres for the translation of Buddhist texts, developing into a large, wealthy monastery. Around 530, it may have been the temporary home of Bodhidharma, or Damo, revered as the founder of Chan 禪 (Zen) Buddhism. ${ }^{51} \mathrm{He}$ is also credited in legend with establishing the practice of martial arts there, although this is extremely unlikely.

Fighting monks from the Temple are first mentioned in the early seventh century. In 621, the "Thirteen Heroic Monks' ${ }^{52}$ famously helped secure victory for Li Shimin 李世民 (599-649)--later the Tang Emperor Taizong 太宗, founder of the Tang Dynasty - against his enemy Wang Shichong 王世充..$^{53}$ In recompense, Li Shimin appointed the Monk Tanzong 窅宗 general-in-chief (da jaangiun 大將軍) in his army. ${ }^{54}$ By the Ming period, the Shaolin Temple was a nationally renowned centre for the martial arts, particularly the use of the staff. In the 1550s, warrior monks from Shaolin were conscripted to fight against Japanese pirate incursions in Fujian in the south-east of China.

${ }^{50}$ See Sakade 2005, p. 278 and passim.

51 See Shahar 2000, p. 15.

52 Recorded by name in the 'List of Thirteen Heroic Monks' on the Shaolin Temple stele, erected 728. See Shahar 2000, pp. 30-1; Tonami p. 22 and p. 26.

53 This event is the subject of Jet Li's (李连杰 Li Lianjie) first film, The Shaolin Temple (Shaolin si 少林寺, dir. Zhang Xinyan/Cheung Kam-Yim 张筑 1982 [1979]), which inaugurated the 1980s gongfu boom in mainland China.

${ }^{54}$ See Shahar 2000, pp. 17-19. 
In the late Ming and Qing periods, Shaolin fighting techniques spread throughout China, as did legends about Shaolin, in particular about a secret branch of the Temple in southern China. Many martial arts styles which emerged during the late Qing, often among secret societies, claim to trace their lineage back to the Temple or its monks.

Having survived almost total destruction three times in its history, most recently during warlord struggles in 1928, the Temple is now flourishing again, thanks to the on-going craze for martial arts both in the west and in China, and schools for learning Shaolin gongfu 功夫 (Kungfu) have sprung up around the world. However, since 1949, the Shaolin tradition has largely been perpetuated outside the religious ambit. In the immediate vicinity of the author's (Wang's) home in Beijing, there is a specialist primary and secondary school for the martial arts, Beïing Shaolin wushu xuexiao 北京少林武术学校, 5.5 which provides training in staff and sword combat, and prepares its students mainly for careers in film and in the security and personal protection industries. Interestingly, the authors were informed there that it would be 'unsightly' (bu haokan 不好看) for mature women to practise animal wushu forms, which are now the preserve of the youthful [see fig. 4].

Animal forms are likewise found in Taijiquan 太極拳, the slow, yielding martial art based on the idea of stillness overcoming movement which arose in the sixteenth century. Taijiquan has been attributed to a legendary 'inner' school of martial arts. Rather than simply training the muscles and physical fitness, it emphasises inner strength and developing a heightened awareness of $q i$ and its dynamic between two opponents. But though Taijiquan echoes some of the concerns of daoyin, most of the individual movements that make up its sequences are common to other more obviously combative Chinese martial arts (wushu 武術), with which it undoubtedly shares a history.

The history of Taimquan as a distinct form with named sequences begins with the Ming general, Qi Jiguang's 墄繼光 (1528-87) Quan j̈ng 拳經 (Classic of the Fist), 29 postures from which resurface in the Taijiquan tradition of the Chen 陳 family community in Henan. By the mid to late nineteenth century, Taïquan flourished in a number of different teaching lin-

${ }^{55}$ http://www.beijingshaolinwuxiao.com/ 


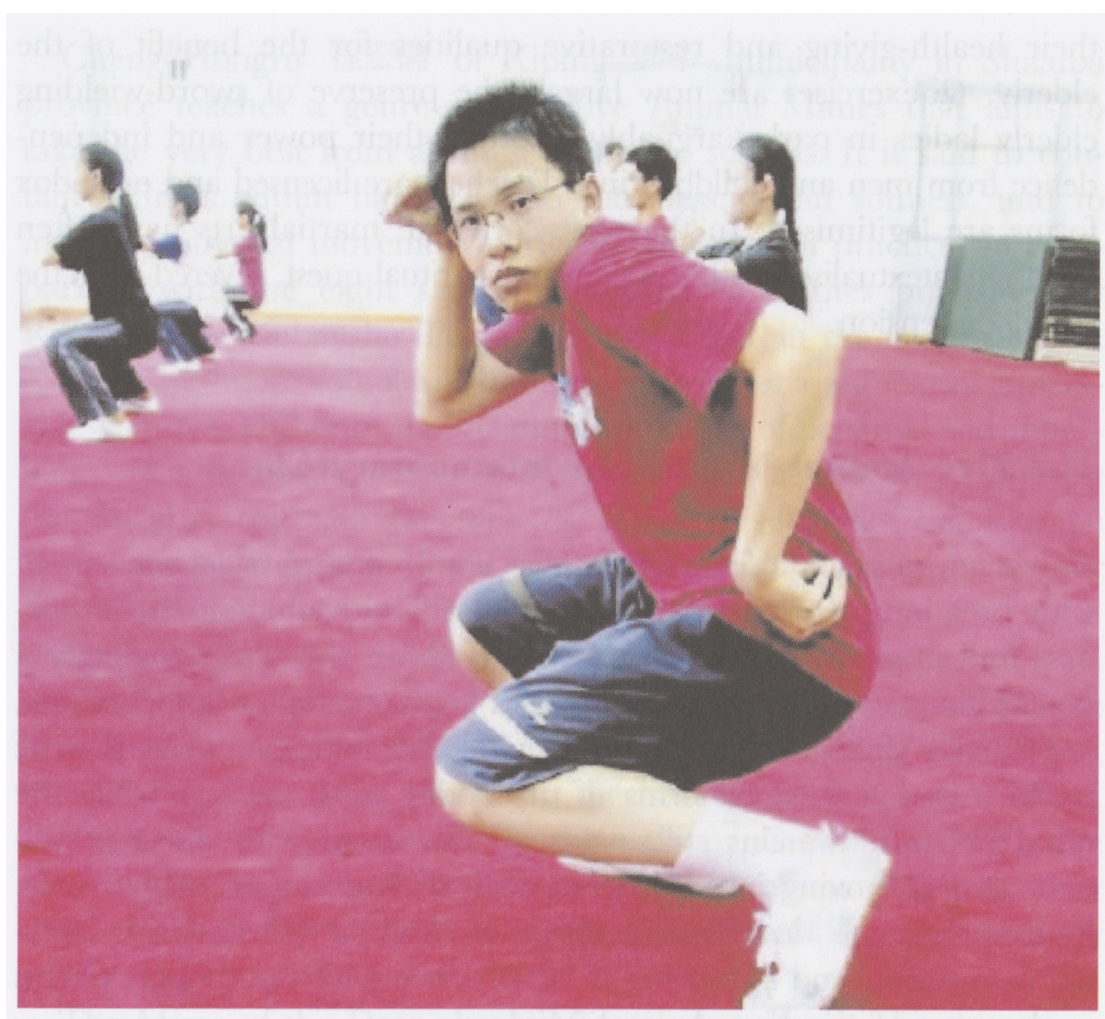

Fig. 4. Students of Guangxi Institute of Chinese Medicine performing the Mime of the Monkey. In the foreground, Wei Ruibin 韦锐斌.

Source: Xinhuashe http://www.photomall.info/photo/detail.jsp?cid=\&searchword $=\% 28 \mathrm{DOC} \_\mathrm{CONTEN}$

eages, such as the Yang 楊, $\mathrm{Wu}$ 吳 and Sun 孫 styles, and was being put to use in military defence systems. ${ }^{56}$

These martial arts military defence systems were seen in action in the Taiping uprising during the nineteenth century and the Boxer Rebellions against foreign hegemony in 1899 and 1900. The 'Boxers' believed that their qi strengthening movements could enable them to fly and protect them against foreign bullets.

Since 1949, the subversive and paramilitary aspects of martial arts have been kept in check, and the Chinese government has stressed

56 See Wile 1996, pp. $x^{-}-\mathbf{x v i}$; 3-30. 
their health-giving and restorative qualities for the benefit of the elderly. Qi exercises are now largely the preserve of sword-wielding elderly ladies in parks, arguably asserting their power and independence from men and childbearing. Teachers are licensed and orthodox forms are legitimised. In the west, 'oriental' martial arts have often been recontextualised within a personal spiritual quest, severed from the social dimension.

\section{The Five Animal Mimes in contemporary China}

Daoyin nowadays is a form of exercise combining physical movement with breathing exercises, practised for self-cultivation, to treat sickness and improve fitness, and as a preventive therapy. Originally a synergistic blend of physical gymnastics and contemplative techniques, it gradually diverged into distinct kinetic and static practices. Kinetic practice is described in terms of the bodily form moving while the mind or spirit remains still; external movement with internal stillness; and $q i$ moving in accordance with the movement of the body. Static practice is described in terms of external stillness with internal movement, and $q i$ moving in accordance with the thoughts. This is also true of the Five Animal Mimes.

In the course of 2000 years of transmission, successive practitioners incorporated their own experience into a plastic, constantly developing tradition, giving rise to a number of schools. Some of these focused on physical training and the literal imitation of animal movements as a means of improving strength and fitness. These types of external practice are what is now generally meant by the Five Animal Mimes. They include the 'hard' (gang 剛) types, which make use of percussion and massage to treat sickness, and even styles of unarmed combat and self-defence, such as Wu qin quan 五离 拳 (Five Animals Boxing) and $W u$ qin sanshou 五离散手 (Five Animals Sparring). The softer styles are concerned with achieving beautiful, graceful movements imbued with strength and vigour, and are akin to dance, as can be seen for example in Wu qin wu 五禽舞 (the Dance of the Five Animals). These types of internal practice use mimesis of the animal's state of mind as a means of directing internal $q i$ and place emphasis on mental techniques. Zifa wuqin xi 自發五禽戲 (the Five Animal Mimes as automatic Qigong/Qigong of self-induced trance) is an example of this. 
Cheng Hongru 程宏儒 of Xiping 興平 municipality in Shaanxi province teaches a genre of the Five Animal Mimes that aims to take the very best from all these disparate schools. It is said to contain softness within hardness and hardness within softness, and to integrate physical movement perfectly with mental practice. In comparison with the eight sets of Five Animal Mimes published by Renmin tiyu chubanshe (People's Sports Press) in the early 1960s, it is richer and more complex. Moreover, it possesses a number of remarkable features. Hitherto, the maximum number of postures and movements in a complete sequence of Mimes was thought to be 30 , but the Shaanxi tradition includes 72 . Thus these forms claim to be predicated on a profound and subtle differentiation of the behaviour of animals and their relations to their habitat.

Here, the Mime of the Bear comprises 14 movements/postures, i.e. the bear lurches (xiong huang 熊晃), the bear sways (xiong bai 熊㨢), the bear pushes (xiong tui 熊推), the bear fights back (xiong kang 熊抗), the bear revolves (xiong yun 熊運), the bear falls over (xiong die 熊跌), the bear fights (xiong dou 熊鬥), the bear pants (xiong xi 熊息), the bear sleeps (xiong mian 熊眠), the bear rages (xiong $n u$ 熊怒), the bear walks (xiong bu 熊步), the bear climbs (xiong pan 熊攀), and the bear swims (xiong yong 熊泳).

The Mime of the Deer also has 14 movements, i.e. the deer turns to look back (lu gu 鹿顧) the deer butts (lu peng 鹿碰), the deer runs (lu ben 鹿奔), the deer walks (lu bu 鹿步), the deer lies down (lu wo 鹿臥), the deer startles (lu jing 鹿驚), the deer stretches (lu shen 鹿伸), the deer trembles (lu dou 鹿抖), the deer grazes (lu jiao 鹿罚), the deer fights (lu dou 鹿鬥), the deer swims (lu yong 鹿泳).

The Mime of the Monkey/Ape has 16 movements, i.e. the monkey spies (yuan kui 猿窥), the monkey fights (yuan dou 猿鬥), the monkey walks (yuan bu 猿步), the monkey shifts position (yuan nuo 猿挪), the monkey dodges (yuan shan 猿閃), the monkey hides (yuan duo 猿躱), the monkey climbs (yuan pan 猿攀), the monkey rolls over (yuan gun 猿滾), the monkey turns somersaults (yuan fan 猿翻), the monkey leaps up (yuan zong 猿縱), the monkey pants (yuan xi 猿息), the monkey prances (yuan teng 猿騰), the monkey makes an offering (yuan xian 猿獻), and the monkey jumps (yuan tiao 猿跳).

The Mime of the Tiger has 14 movements, i.e. the tiger crouches ( $h u j u$ 虎踞), the tiger lies down ( $h u$ wo 虎臥), the tiger prowls (hu $b u$ 虎步), the tiger scratches ( $h u$ zhua 虎抓), the tiger bites (hu yao 虎咬), the tiger pounces ( $h u b u$ 虎捕), the tiger leaps up ( $h u$ zong 


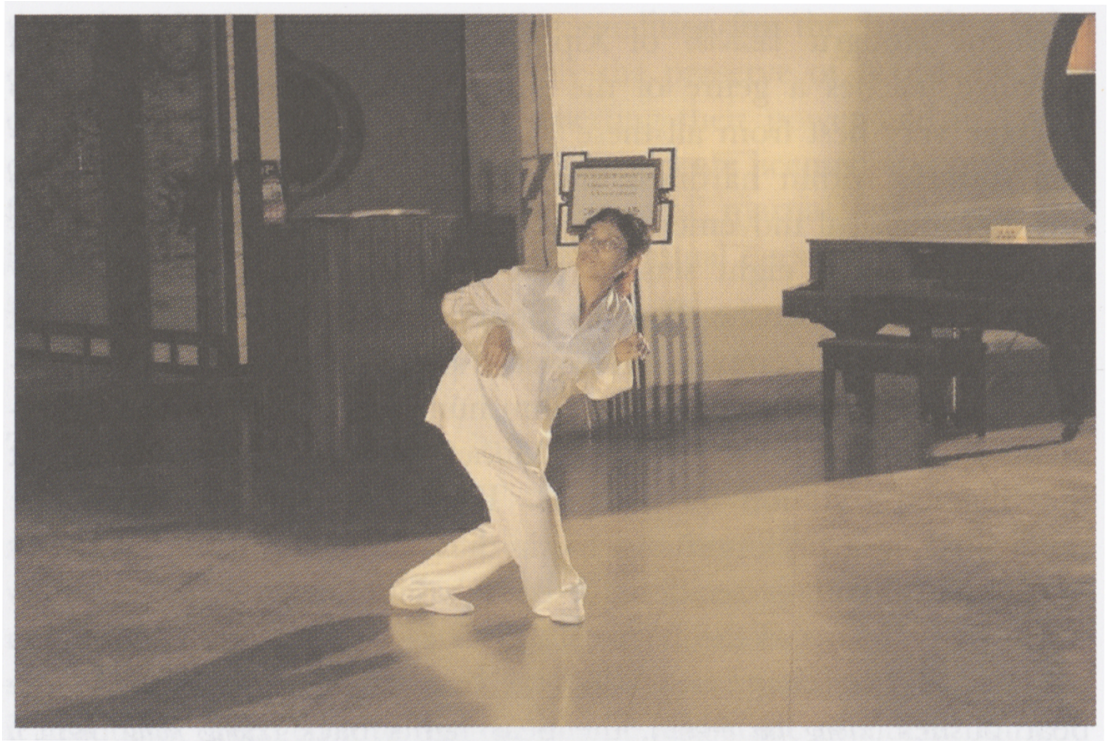

Fig. 5. Ms Wang Jian †健 performs a balletic version of the Five Animal Mimes (Fragrant Hills Hotel, Beijing, 15 September 2005, photograph by Wang Shumin)

虎縱), the tiger roars (hu xiao 虎㗲), the tiger pushes (hu an 虎按), the tiger jumps (hu tiao 虎跳), the tiger lies on its belly ( $h u$ fu 虎伏), the tiger spies (hu kui 虎窅), the tiger swims (hu yong 虎泳).

The Mime of the Crane has 14 movements, i.c. the crane stands up (he qi 鶴起), the crane walks (he bu 鶴少), the crane turns around (he zhan 鶴展), the crane stands still (he li 鶴泣), the crane shows itself (he liang 鶴亮), the crane flies (he fan 鶴翻), the crane soars (he xiang 鶴翔), the crane preens itsclf (he xiu 鶴修), the crane startles (he jing 鶴驚), the crane calls (he ming 鶴鳴), the crane breathes (he xi 鶴息), the crane lands (he luo 鶴). ${ }^{37}$ [Sec fig. 5]

As part of the reinvention of traditional medicine from the 1950s onward, the Five Animal Mimes have been medicalised as a method of preventing specific discases and strengthening organ systems. Since most of the exercises are easy to learn and perform, they are particularly suitable for elderly and sick people.

5 Iiu Yaowu 1996, p. +2. 
In 'Hua Tuo zouqin xi dui renti zuoyong xin lun' 佗五禽戲對人體作用新論 (A new discussion of the effects of Hua Tuo's Five Animal Mimes on the human body), published in 2004, Su Yaping 蘇亞平 summarises the putative health benefits of the Mimes as follows:

The Mime of the Tiger relates to the liver. By practising it, one can succeed in soothing the liver and rectifying $q i$. The Mime of the Deer relates to the kidney. By practising it, one can succeed in promoting $q i$, supplementing the kidney and strengthening the waist/lumbar region. The Mime of the Bear relates to the spleen. By practising it, one can keep the qi dynamics of the Triple Burner (sanjiao 三焦) free and unobstructed, harmonise the upward and downward movement of $q i$ in the stomach and spleen, and enable the digestive processes to function in a healthy fashion, thus increasing the transformation and generation of $q i$, blood and bodily fluids. The Mime of the Monkey relates to the heart. By practising it, one can nourish the heart and calm the spirit, clarify the understanding and improve intellect. The Mime of the Bird relates to the lungs. By practising it, one can tonify the lungs and expand the thorax, and regulate and disinhibit the dynamics of $q i$ [breath]..$^{58}$

With the modern Chinese concern for providing an 'evidence base' for Traditional Chinese Medicine, daoyin has become the subject of controlled trials. ${ }^{59}$ Cui Yongsheng 崔永勝 recently published a study of the effects of the Five Animal Mimes on the physical and mental wellbeing of middle-aged and elderly female subjects. He concludes that after practising 'Five Animal Mimes Qigong gymnastics for health' for three months, the subjects achieved a marked improvement in physiological signs including blood pressure, pulse rate, waist to hip ratio, and lung capacity. He also reports positive changes in mood and other psychological factors. ${ }^{60}$

Anecdotal evidence abounds. In June 2006, Su Guiqiu 蘇桂秋 of the Xinhua News Agency reported the case of 78 year-old Jiang Yufan 姜玉範, for the past 20 years head of the Community Sports Training Centre at the Zhongshan District headquarters of Dalian Sports Services [See fig. 6]. He is the picture of robust good health. Though somewhat hard of hearing, he has exceptionally keen eyesight, and can see and dexterously retrieve a pin dropped on the

${ }^{58}$ Su Yaping 2004, pp. 75-6.

59 Cf. for a social history of the development of the concept of evidence in TCM see Lei 2002.

${ }^{60}$ Cui Yongsheng 2004, pp. 1504-6. 


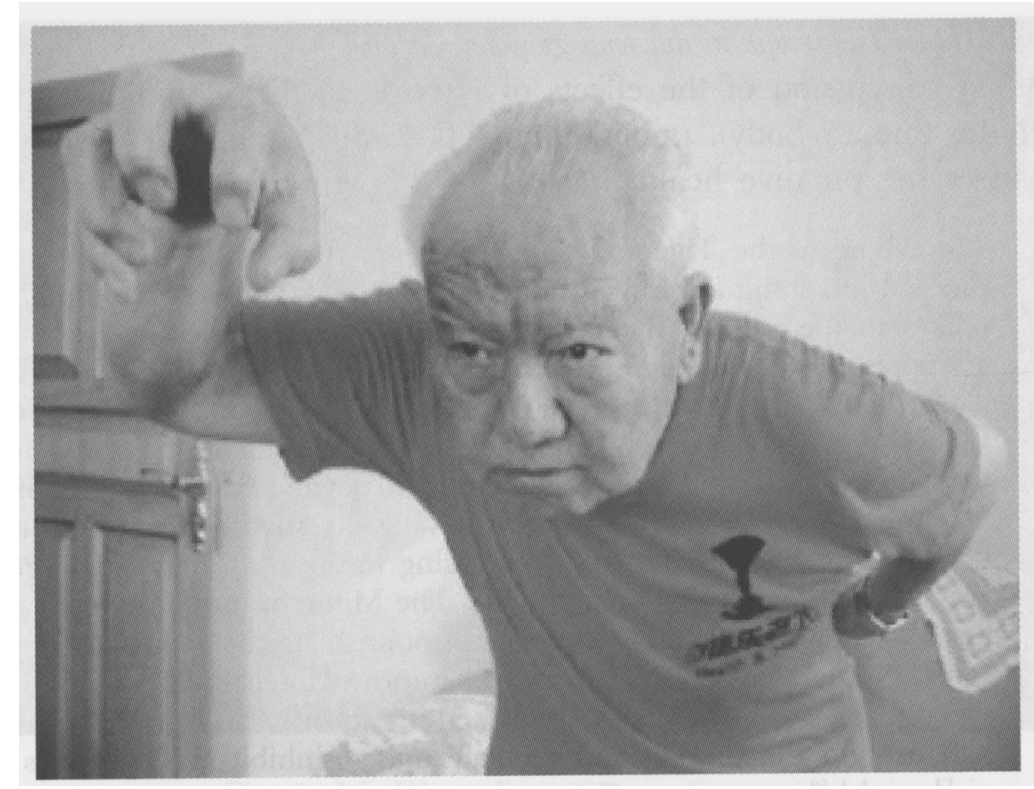

Fig. 6. Eighty-year-old Jiang Yufan performs the Mime of the Tiger

Source: Dalian wanbao 大连晚报 28.08.2004

http://www.dlwb.com.cn/dlwb/news/jsp/shownews.jsp?id=48797

floor. But in 1974, Jiang Yufan fell ill with hepatitis. After almost a year's treatment, he showed no signs of improvement and was sent to his home town to convalesce. There he studied the Five Animal Mimes with the elderly Jiang Hongqing 姜洪清. Having practised the Mimes assiduously for 14 months, and beginning to feel healthier, he attended Shenyang Medical College for a check-up. Much to his astonishment, all the test results came back normal. He underwent further tests at four or five major hospitals, all of which confirmed the original results.

The General Administration of Sport of China has assigned a high priority to promoting the Five Animal Mimes for health and fitness, and has launched several publicity campaigns to encourage uptake. It is now included in the sports programmes of a number of universities. In 2003, the Five Animal Mimes was one of just four methods of qigong for health recommended by the Health Qigong Administration Centre under the General Administration of Sport of China.

As daoyin is thoroughly integrated into Chinese public health policy, the 'Five Animal Mimes' have become part of the communal 
daily practice that advertises the cohesive qualities of Chinese society, their ancient potency woven into the persistent moral fibre that holds together a country in rapid transformation. University students demonstrate their commitment to collective health by impersonating birds and beasts. Tiny gongfu pupils from Chinese wushu academies tour the world with hair-raising performances of the mimes of a four animal tradition, in which the hard forms of the leopard, the tiger, the grasshopper and the eagle seem to boast of China entering upon a new age. No longer the 'sick man of the east', China is not only young, healthy and robust, but fully in charge of its traditions, which we are left in no doubt are here to stay.

\section{References}

Primary sources

Bencao Gangmu: Li Shizhen 李时珍 (Ming), Bencao Gangmu (Xin jiaozhu ben) 本草纲目 (新校注本), Liu Hengru 刘衡如 et al. (eds.), Beijing: Huaxia chubanshe, 2002.

Cheng Lin 程林 (Qing period, 1644-1911), Yi xia zhi yan 㗇后言, Zhongguo yixue dacheng, vol. 13, Shanghai dadong shuju, 1936.

Daoyin tu 筫引圖 (Daoyin Chart): Mawangdui hanmu bo zhengli xiaozu 馬王堆, 漢基帛書整理小組 (Silk text editing and collating team of Mawangdui Han tombs) 1979, Daoyin tu 筫引圖, Bejing wenwu chubanshe.

Hou Hanshu 後漢書 (History of the Later Han), Zhonghua shuju, 1965.

Huainanzi: Liu Wendian 劉文典 (ed.) 1992, Huainanzi honglie jijie 淮南子鸿烈集解 (Collected Explanations of the Huainanzi honglie), Taibei: Wenshizhe.

Huangdi neijing: Lingshu 黄帝內經·政橹, Renmin weisheng chubanshe, 1963.

Lü Shi chunqiu 呂氏春秋 (Mr Lü's Spring and Autumn Annals), Baizi quanshu 百子全書, vol. 5, Zhejiang renmin chubanshe, reproduction of 1919 lithographic edition.

Lü Shi chunqiu jiaoshi 呂氏春秋校㔍 (Mr Lü's Spring and Autumn Annals Annotated), annotated by Chen Qiyou 陳奇缺, Shanghai: Xuelin, 1995.

Sanguo zhi 三國志 (Chronicles of the Three Kingdoms), Zhonghua shuju, 1962.

Taipingïng hëiao 太平經合校, Beijing: Zhonghua shuju, 1979.

Tao Hongjing 陶弘景 (attr.), Yangxing yanming lu 基性延命錄 (Account of Cultivating Nature and Extending life), Latter volume, 'Daoyin anqiao' 導引按 蹺 (Therapeutic gymnastics and massage) in Daozang yishu 14 zhong 道藏硻 書十四種 (Fourteen Medical Texts from the Daoist Canon), vol. 12, Shanghai hanfen lou yingyin zhengtong 'Daozang' ben 上海涵芬樓影印正統(道藏)本, no publication date.

Yinshu 引書: Zhangïashan 247 hao hanmu zhujian zhengli xiaozu 張家山二四七號漢基竹簡整理小組 (Bamboo slip editing and collating team of Zhangjiashan Han tomb 247) 2002, Zhangizashan hanmu zhujian: Yinshu 張家 山漢基竹简·書 (Bamboo Slip Texts from the Zhangjiashan Han Tombs: Yinshu), Beijing wenwu chubanshe.

Zhou Lüjing 周履靖, Chi feng sui 赤風 (Marrow of the Crimson Phoenix), Congshu

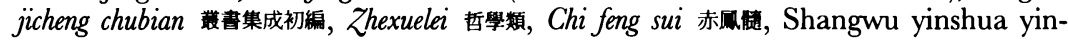
shuguan, 1959. 


\section{Secondary sources}

Bodde, D. 1975, Festivals in Classical China: New Year and other annual observances during the Han Dynasty 206 BC-AD 220, Princeton: Princeton University Press.

Bray, F., G. Métailié and V. Dorofeeva-Lichtmann (eds.) 2007 (forthcoming), The Warp and the Weft: Graphics and text in the production of technical knowledge in China, Leiden: Brill.

Chen Guying 陳嵮應 1991 [1983], Zhuangzi Jinzhu Finyi 狮子今注今詀 (Zhuangzi with Modern notes and Translations), Beijing: Zhonghua shuju.

Cui Yongsheng 崔永 2004, 'Jianshen qigong Wuqin xi duanlian dui zhonglaonian nüxing

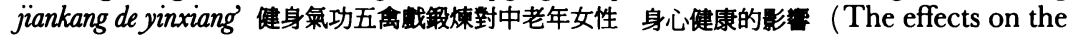
health and fitness of middle-aged and elderly female subjects of practising Five Animal Mimes Qigong gymnastics), Beijing Tiyu Daxue xuebao 北京䯈育大學基報, issue 11.

Despeux, C. 1988, La moelle du phénix rouge. Santé et longue vie dans la Chine du XVI' siècle, Paris: Guy Trédaniel.

— 1989, 'Gymnastics: The ancient tradition', in L. Kohn and S. Yoshinobu (eds), Taoist Meditation and Longevity Techniques, Ann Arbor: Center for Chinese Studies, University of Michigan, 225-61.

— 1990,Taiji Quan, art martial, technique de longue vie, Paris: Guy Trédaniel.

Engelhardt, U. 1987, Die klassische Tradition der Qi-Übungen (Qigong): Eine Darstellung anhand des Tang-zeitlichen Textes Fuqi Jingyi Lun von Sima Chengzhen, Stuttgart: Franz Steiner.

— 2000, 'Longevity Techniques and Chinese Medicine', in L. Kohn (ed.), Daoism Handbook, vol. 1, Leiden: Brill, 74-108.

Graham, A. C. (tr. and notes) 1981, Chuang-tzu. The Seven Inner Chapters and Other Writings, London: George Allen and Unwin.

Guo Qingfan 郭度藩 1961, Zhuangzi jishi 莊子集釋 (Collected Commentaries on Zhuangzi), vol. 3, Zhonghua shuju.

Harper, D. 1985, 'A Chinese Demonography of the Third Century BC', Harvard Fournal of Asiatic Studies, 45: 459-98.

Harper, D. 1998, Early Chinese Medical Literature: The Mawangdui medical manuscripts, London: Kegan Paul International.

He Ning 何察 1998, Huainanzi jühi 淮南子集釋 (Collected Commentaries on Huainanzi) in Xinbian zhuzi jicheng 新編諸子集成, part 1, Zhonghua shuju.

He Zhiguo 何志圆 and V. Lo 1996, 'The Channels: A preliminary examination of a laquered figurine from the Western Han period', Early China, 21: 81-123.

Knoblock, J. and J. Riegel 2000, The Annals of Lü Buwei: A complete translation and study, Stanford: Stanford University Press.

Kohn, L. (ed.) 1989, Taoist Meditation and Longevity Techniques, Ann Arbor: Center for Chinese Studies, University of Michigan.

Lei, Sean Hsiang-Lin 雷祥 2003, 'How Did Chinese Medicine Become Experiential? The political epistemology of Jingyan', Positions, 10:2, 333-64.

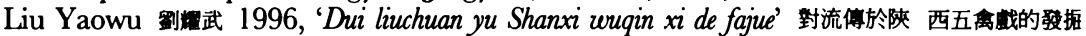
(Explorations of the Five Animal Mimes as transmitted in Shaanxi), Shanxi zhongyi Xueyuan xuebao 傸西中學院學報, vol. 19, issue 4.

Lloyd, G. and N. Sivin 2002, The Way and the Word: Science and medicine in early Greece and China, New Haven and London: Yale University Press.

Lo, V. 1998, 'The Influences of Yangsheng Culture on early Chinese Medical Theory', Ph.D. thesis, School of Oriental and African Studies, University of London.

- 2006, 'Animating the Body in the Healing Arts of China', unpublished conference paper presented at Daoism and the Contemporary World-Daoist Cultivation in Theory and Practice, Abbey Frauenwörth, Germany.

2007 (forthcoming), 'Imagining Practice: Sense and sensuality in early Chinese medical illustration', in F. Bray, G. Métailié and V. Dorofeeva-Lichtmann (eds.), 
The Warp and the Weft: Graphics and text in the production of technical knowledge in China, Leiden: Brill.

Loewe, M. 2004, The Men who Governed China in Han Times, Leiden: Brill.

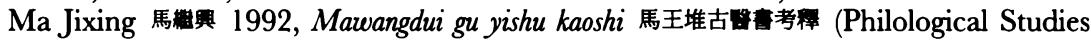
of Ancient Medical Books from Mawangdui), Hunan kexue chubanshe.

Mair, V. H. 1994, Wandering on the Way: Early Taoist tales and parables of Chuang Tzu, Honolulu: University of Hawaii Press.

Needham, J. 1956, Science and Civilisation in China, Vol. II: History of Scientific Thought, with the research assistance of Wang Ling, Cambridge: Cambridge University Press.

Sakade Y. 2005, 'Daoism and the Dunhuang Regimen Texts', in V. Lo and C. Cullen (eds.), Medieval Chinese Medicine: The Dunhuang medical manuscripts, London: RoutledgeCurzon, 278-90.

Shahar, M. 2000, 'Epigraphy, Buddhist Historiography, and Fighting Monks: The case of the Shaolin Monastery', Asia Major, 13.2: 15-36.

Sterckx, R. 2002, The Animal and the Daemon in Early China, SUNY Series in Chinese Philosophy and Culture, Albany: State University of New York Press.

Sterckx, R. 2005, 'Animal Classification in Ancient China', East Asian Science, Technology and Medicine, 23: 96-123.

Su Yaping 蘇亞平 2004, 'Hua Tuo wuqin xi dui renti zuoyong xin lun' 佗五禹 新人作用新論 (A new discussion of the effects of Hua Tuo's Five Animal Mimes on the human body), Zhongyi jiaoyu 中教育 (ECM), vol. 23, issue 5 .

Sumiyo Umekawa 總代 2005, 'Tiandi yinyang jaaohuan dalefu and the art of the bedchamber', in V. Lo and C. Cullen (eds.), Medieval Chinese Medicine: The Dunhuang medical manuscripts, London: RoutledgeCurzon, 278-90.

Tonami, M. 1990, The Shaolin Monastery Stele on Mount Song, trans. and annotated by P. A. Herbert, Kyoto:Istituto italiano di cultura, Scuola di studi sull'Asia orientale.

Wile, D. 1996, Lost Tai chi Classics from the late Ch'ing Dynasty, Albany: SUNY.

Wilms, S. 2007, 'Tao Hongjing', in W. Bynum and H. Bynum (eds.), Dictionary of Medical Biography, Westport: Greenwood Press. vol. 5, 1219-20. 